Research Paper

\title{
Differential Expression Profile of Long Non-coding RNAs during Differentiation of Cardiomyocytes
}

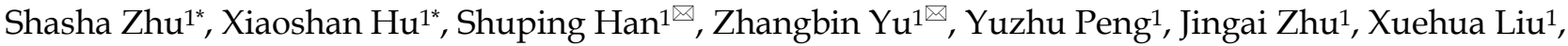 \\ Lingmei Qian ${ }^{2}$, Chun Zhu ${ }^{1}$, Mengmeng Li1, Guixian Song ${ }^{2}$, Xirong Guo ${ }^{1}$
}

1. State key Laboratory of Reproductive Medicine, Department of Pediatrics, Nanjing Maternity and Child Health Care Hospital Affiliated to Nanjing Medical University, Nanjing 210029, China.

2. Department of Cardiology, The First Affiliated Hospital of Nanjing Medical University, Nanjing, Jiangsu 210029, China

* The authors have contributed equally to this study and they should be regarded as joint first authors.

$\triangle$ Corresponding author: SP Han, ZB Yu, Department of Pediatrics, Nanjing Maternity and Child Health Care Hospital of Nanjing Medical University, No. 123 Tian Fei Xiang, Mo Chou Road, Nanjing 21004, China. E-mail: shupinghan@njmu.edu.cn (SP Han); zhangbinyu@njmu.edu.cn (ZB Yu). Tel: +86-025-52226561, Fax: +86-025-52226561.

(c) Ivyspring International Publisher. This is an open-access article distributed under the terms of the Creative Commons License (http://creativecommons.org/ licenses/by-nc-nd/3.0/). Reproduction is permitted for personal, noncommercial use, provided that the article is in whole, unmodified, and properly cited.

Received: 2013.10.09; Accepted: 2014.03.07; Published: 20I4.03.28

\begin{abstract}
Many long non-coding RNAs (IncRNAs) are species specific and seem to be less conserved than protein-coding genes. Some of them are involved in the development of the lateral mesoderm in the heart and in the differentiation of cardiomyocytes. The purpose of the study was to investigate the expression profiles of IncRNAs during the differentiation of PI9 cells into cardiomyocytes, with a view to studying the biological function of IncRNAs and their involvement in the mechanism of heart development. First, we observed the morphology of PI 9 cells during differentiation using an inverted microscope. Then, cardiac troponin $\mathrm{T}(\mathrm{cTnT})$ expression was detected to validate that the cells had successfully differentiated into cardiac myocytes by real-time reverse transcriptase polymerase chain reaction (real-time RT-PCR) and western blotting. Lastly, the expression profile of IncRNA genes was obtained using an IncRNA microarray and real-time RT-PCR analyses. The microarray results showed that 40 IncRNAs were differentially expressed, of which 28 were upregulated and 12 were downregulated in differentiated cardiomyocytes. The differentially expressed IncRNAs were further validated. Our results illustrated a critical role of IncRNAs during the differentiation of PI 9 cells into cardiac myocytes, which will provide the foundation for further study of the biological functions of IncRNAs and the mechanism of heart development.
\end{abstract}

Key words: IncRNAs; differentiation; caridiomyocytes; microarrays.

\section{Introduction}

The heart is the first functional organ that is developed in the process of embryonic development. It is very important for development that the heart is healthy. Numerous studies have revealed the accurate regulation of key molecular pathways during embryonic development, particularly in the cardiovascular system. Haploinsufficiency of essential genes often leads to cardiac malformations [1], which are the most common major congenital defects, with a prevalence of approximately eight in every 1,000 newborn infants [2].
The human transcriptome is composed of not only a large set of protein-coding messenger RNAs (mRNA), but also many non-protein coding transcripts that have structural, regulatory or unknown functions. Over the last decade, much attention focused on the microRNAs (miRNAs), a class of small non-coding RNAs that are involved in various biological and pathological processes [3, 4]. More recently, long non-coding RNAs (lncRNAs), generally defined as non-coding RNAs of more than 200nt in length without known protein-coding function [5], 
have risen to prominence, with central roles in a diverse range of functions in cell biology [6,7]. In contrast to miRNAs, lncRNAs have not been fully investigated. A handful studies have indicated that dysregulation of lncRNAs result in aberrant gene expression associated with cancers [8-10]. Although an increasing number of lncRNAs have been characterized, the role of lncRNAs in the differential of cardiomyocytes has not been investigated.

The P19 mouse embryonal carcinoma cell line is multipotent and can differentiate into cardiac myocytes with embryoid body formation in the presence of dimethylsulfoxide (DMSO) [11]. Thus, P19 cells have been used to study cardiac-specific transcription factors and upstream signaling pathways in cardiac differentiation [12-14]. Therefore, P19 cells are a suitable model for studying cardiac differentiation at the molecular and functional levels [15].

In this study, we initially identified differentially expressed lncRNAs during the differentiation of P19 cells using an lncRNA microarray. We subsequently validated the microarray results by real-time quantitative reverse transcription PCR (real-time qRT-PCR) for specific differentially expressed lncRNAs.

\section{Results and Discussion}

\section{PI 9 cells differentiation}

P19 cells differentiate into cardiac myocytes in the presence of DMSO. The efficiency of differentiation depends on the prior formation of non-adhering aggregates [17]. We observed and photographed the morphological changes in P19 cells using an inverted microscope to investigate the process of P19 cell differentiation. We discovered that P19 cells aggregated during the first 4 days and there were beating cell colonies on day 10 (Figure 1). The myocyte differentiation marker cTnT was detected on day 0 and day 10 , respectively, to validate that the cells had differentiated into cardiac myocytes. As shown in Figure 2 and Figure 3, mRNA expression and protein expression of cTnT were much higher on day 10 compared to day 0 . Thus, the beating cell colonies generated on day 10 of P19 cell differentiation, and the high expression of cTnT, demonstrated that the cells had differentiated into cardiac myocytes.

\section{IncRNA microarray.}

LncRNA microarrays are powerful tools for studying the biological function of lncRNAs. We conducted lncRNA microarray analysis on P19 cells at day 0 and day 10 of DMSO exposure. According to the microarray data, we selected lncRNAs that were upregulated by more than five-fold and downregulated by more than three-fold. In addition, poorly con- served lncRNAs were excluded. The conservation of lncRNAs was determined using the online Basic Local Alignment Search Tool (http:/ / bla st.ncbi.nlm.nih.gov/Blast.cgi). Ultimately, 40 differentially expressed lncRNAs that were highly conserved in cardiac myocytes (day 10) compared to normal P19 cells (day 0) were identified (Table 1). Among them, 28 were upregulated and 12 were downregulated. We randomly chose five upregulated IncRNAs (ENSMUST00000159006, uc009byc.1, AK089560, ENSMUST00000101005, ENSMUST000001 24503) and three downregulated lncRNAs (uc007keu.1, AK028257, BC030682) for qRT-PCR validation (Table 2).

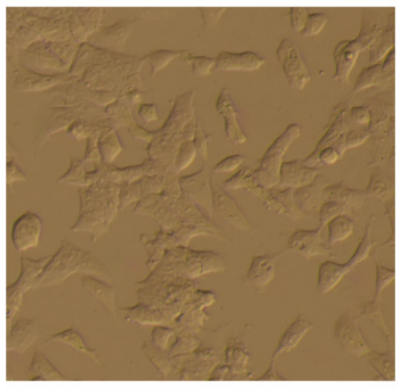

Day 0

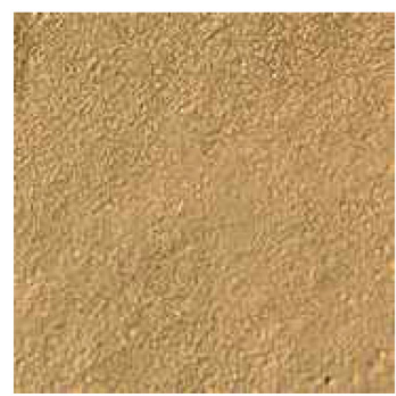

Day 8

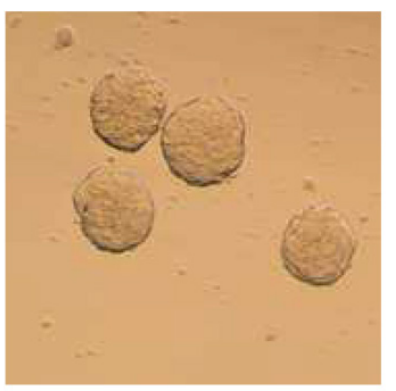

Day 4

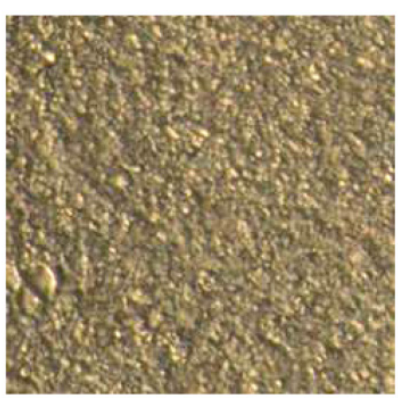

Day 10
Figure I: Morphology of PI9 cells during differentiation into cardiac myocytes (day 0 , day 4 , day 8 , day 10). PI 9 cells were aggregated for 4 days and colonies of beating cells were observed on day 10 under an inverted microscope, as described in Materials and methods.

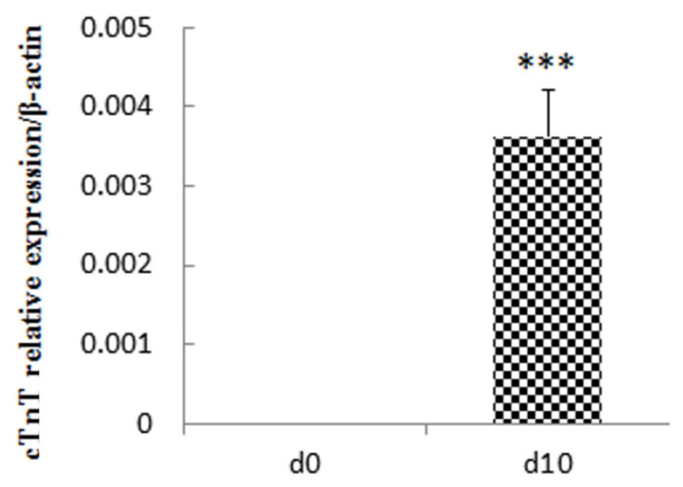

Figure 2: Relative expression of cTnT at day 10 compared with day 0 . The experiment was repeated three times with consistent results. $* * * p<0.001$ 


\section{Day o Day 10}

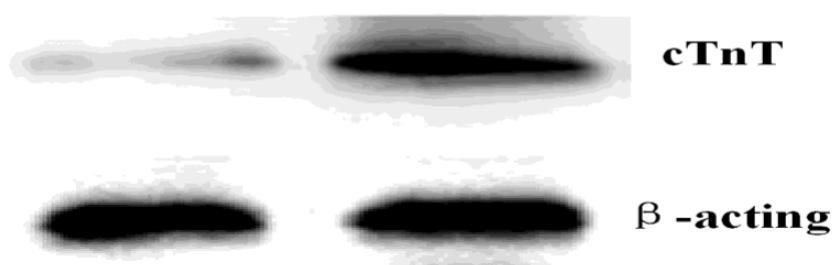

Figure 3: Expression of the cTnl protein in PI 9 cells. Total proteins were isolated from PI 9 cells and analyzed by western blotting. Lane I, day 0; Lane 2, day 10. The experiment was repeated three times with consistent results.

Table I. 40 differentially expressed IncRNAs.

\begin{tabular}{|c|c|c|c|c|c|}
\hline Regulation & lncRNA & chromosomal localization & RNA length & Start locus & Stop locus \\
\hline \multirow{28}{*}{$\begin{array}{l}28 \text { up-regulated } \\
\text { lncRNAs }\end{array}$} & AK158639 & chr2 & 417 & 169458512 & 169458928 \\
\hline & uc007vie.1 & chr15 & 4168 & 12959401 & 12963569 \\
\hline & ENSMUST00000159006 & chr6 & 253 & 52108522 & 52112019 \\
\hline & AK166199 & chr13 & 1351 & 16122089 & 16123440 \\
\hline & AK052877 & chr19 & 1301 & 30638978 & 30640279 \\
\hline & uc009biz.1 & chr6 & 606 & 36664928 & 36665534 \\
\hline & uc009pal.1 & chr9 & 3270 & 41388823 & 41400910 \\
\hline & uc009eqi.1 & chr6 & 2534 & 143777066 & 143779600 \\
\hline & ENSMUST00000101005 & chr6 & 1302 & 119912384 & 119913686 \\
\hline & ENSMUST00000124503 & chr11 & 454 & 35163570 & 35164287 \\
\hline & AK020106 & chr11 & 802 & 69615637 & 69616437 \\
\hline & AK142834 & $\operatorname{chr} X$ & 2388 & 118021841 & 118024227 \\
\hline & uc007cpz.1 & chr1 & 2470 & 135197537 & 135200007 \\
\hline & uc007prv.1 & chr13 & 2198 & 21925626 & 21929399 \\
\hline & uc009byc. 1 & chr6 & 545 & 52122879 & 52124051 \\
\hline & AK078053 & chr18 & 1378 & 36459754 & 36461132 \\
\hline & NR_024257 & $\operatorname{chr} 2$ & 4066 & 9802872 & 9808394 \\
\hline & AK089560 & chr5 & 2683 & 13525726 & 13528408 \\
\hline & AK142308 & chr18 & 1262 & 37965377 & 37966636 \\
\hline & AK046177 & chr13 & 606 & 117639650 & 117640255 \\
\hline & AK135062 & chr7 & 2464 & 104057136 & 104059598 \\
\hline & AK138321 & chr11 & 2303 & 47744849 & 47747149 \\
\hline & uc008sdp.1 & chr4 & 3039 & 22409926 & 22412965 \\
\hline & uc008fug.1 & chr18 & 948 & 83172461 & 83173409 \\
\hline & AK028129 & chr3 & 2428 & 96043315 & 96045742 \\
\hline & uc008xbx.1 & chr5 & 802 & 34516538 & 34517340 \\
\hline & uc008euf.1 & chr18 & 1629 & 43480650 & 43482279 \\
\hline & ENSMUST00000127359 & chr14 & 344 & 47007193 & 47008957 \\
\hline \multirow{12}{*}{$\begin{array}{l}12 \text { down-regulated } \\
\text { lncRNAs }\end{array}$} & uc007keu.1 & chr11 & 1635 & 75565382 & 75579340 \\
\hline & AK033485 & chr1 & 2241 & 54532201 & 54534442 \\
\hline & uc007pyj.1 & chr13 & 1179 & 28700386 & 28977221 \\
\hline & uc008sac.1 & chr4 & 1060 & 11893711 & 11921427 \\
\hline & AK137254 & chr7 & 5124 & 127773275 & 127778400 \\
\hline & AK028257 & chr14 & 272 & 55735163 & 55735434 \\
\hline & ВС030048 & chr17 & 1092 & 35087185 & 35088238 \\
\hline & ВC030682 & chr7 & 1343 & 71031236 & 71032537 \\
\hline & ENSMUST00000117553 & chr2 & 1125 & 111840336 & 111841461 \\
\hline & ENSMUST00000172121 & chr6 & 291 & 64941211 & 64941502 \\
\hline & AK010244 & chr2 & 1771 & 125082798 & 125084785 \\
\hline & uc008men.1 & chr2 & 1771 & 125082798 & 125084785 \\
\hline
\end{tabular}


Table 2. IncRNAs differentially expressed between cardiomyocytes that differentiated from PI9 cells (day I0) compared with normal cells (day 0 ).

\begin{tabular}{llllll}
\hline up-regulated lncRNA & fold change & GeneSymbol & down-regulated lncRNA & fold change & GeneSymbol \\
\hline ENSMUST00000159006 & 46.21 & Gm15051 & uc007keu.1 & 8.07 & Ywhae \\
uc009byc.1 & 21.50 & AK142386 & AK028257 & BC030682 & 3.4 \\
AK089560 & 15.47 & & & \\
ENSMUST00000101005 & 6.29 & Wnk1 & & \\
ENSMUST00000124503 & 5.11 & Gm12122 & & \\
\hline
\end{tabular}

\section{Validation of differentially expressed IncRNAs}

We performed real-time qRT-PCR expression analysis on P19 cells at day 0 and day 10 to confirm the microarray results. Using GAPDH as a normalization control, the statistics demonstrated that four out of the five upregulated lncRNAs $(\mathrm{P}=0.038$, 0.000016, 0,022 and 0.017 for ENSMUST00000159006, uc009byc.1, AK089560, ENSMUST00000124503, respectively) and two of the three downregulated lncRNAs $(\mathrm{P}=0.00012$ and 0.001 for AK028257 and uc007keu.1, respectively) showed significantly different expressions (Figure 4). In addition, we validated the eight differentiated expressed lncRNAs at different time points during the differentiation. D0, $\mathrm{d} 4, \mathrm{~d} 6, \mathrm{~d} 8, \mathrm{~d} 10$ were chosen as the time points. As shown in the figure 5 , the expressed trends during the differentiation are consistent with the comparison between $\mathrm{d} 0$ and $\mathrm{d} 10$. The major difference might be the beginning time of the change was different.

\section{Discussion}

Congenital heart defects (CHD) are the most common major congenital malformation, accounting for approximately $40 \%$ of perinatal deaths and more than one fifth of deaths in the first month of life [18]. Although many studies have focused on heart development in recent decades, details of the mechanism remain unclear $[19,20]$. P19 cells are isolated from an experimental embryo-derived mouse teratocarcinoma and can differentiate into cardiac myocytes with embryoid body formation in the presence of DMSO [21]. Thus, we simulated heart development in vitro by differentiating P19 cells into cardiomyocytes.

This study focused on determining the lncRNAs expression profile during cardiomyocyte differentiation and explaining the differences between cardiomyocytes and undifferentiated P19 cells. We identified 40 differentially expressed lncRNAs (28 upregulated and 12 downregulated). Real-time qRT-PCR validated four of five upregulated and two of three downregulated lncRNAs.

Some researchers have demonstrated that the expression of many lncRNAs is different during development and that their functions range from the control of pluripotency to lineage specification [22, 23]. In theory, lncRNAs have intrinsic cis-regulatory capacity, which has been confirmed and whose mechanism has been described. Increasing numbers of reports show that lncRNAs can play a role in both cis and trans [24, 25], and more direct experimental studies are required to determine the precise proportion of cis regulators. Regulating the expression of some lncRNAs may influence the expression of their neighboring protein-coding genes, including several master regulators of cellular differentiation [26-28]. It is in the early stage that the role of lncRNAs in heart development has attracted much attention from researchers. Indeed, two lncRNAs, Fendrr and Braveheart (Bvht), were recently uncovered to be involved in the development of the lateral mesoderm in the heart and the differentiation of cardiac myocytes, respectively $[29,30]$. Deficiency of Fendrr, particularly in the nascent lateral plate mesoderm, can result in a thin ventricular wall of the heart. Fendrr regulates the expression of certain core transcription factors in heart development by modulating the epigenetic profile of cells to generate cardiac hypoplasia [29]. In a similar way to Fendrr, Bvht interacts with SUZ12, a component of PRC2, to alter cardiomyocytes differentiation and retain the cardiac phenotype in neonatal cardiomyocytes [30].

Most of the four up-regulated and two down-regulated lncRNAs have no official Human Genome Nomenclature Committee symbol and their function is still unclear. However, some studies have been shown that Ywhae play a critical role in many diseases, such as HIV neurocognitive impairment [31], neuronal migrational defects [32], bipolar disorder [33] and endometrial stromal sarcoma [34].

Although we have identified some differentially expressed lncRNAs during the cardiac differentiation, it is too early for us to confirm their relationship with cardiac malformation. Therefore, subgroup analysis of lncRNAs should be performed to explore this relationship in the future. In addition, most lncRNAs have a distinct spatial and temporal specificity in the process of organismal differentiation and development. It has been shown that lncRNAs have different expression patterns in different parts of the brain [35]. 
We should sample more cells from different times in the process of differentiation, such as $\mathrm{d} 4, \mathrm{~d} 6$ and $\mathrm{d} 8$, to
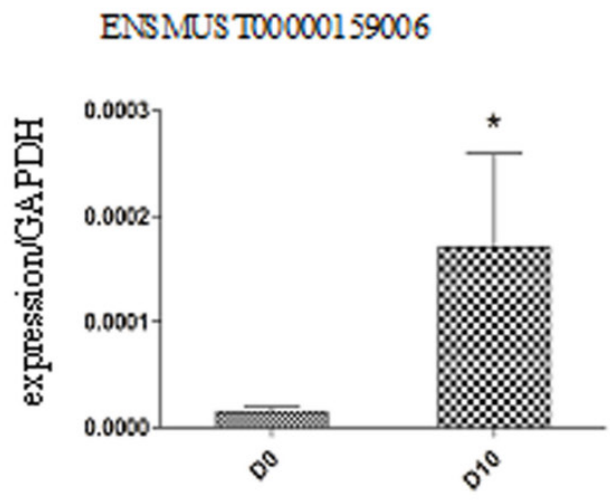

AK089560

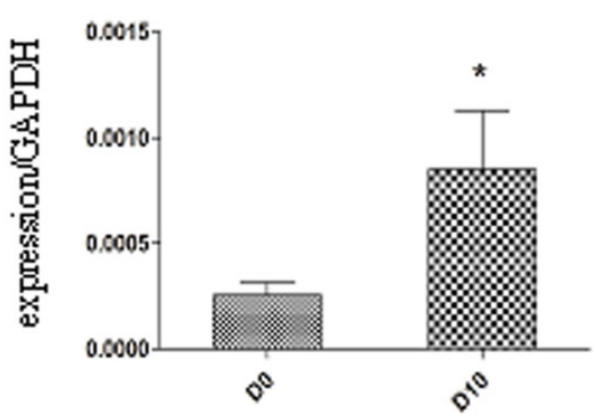

ENSMUS T00000101005

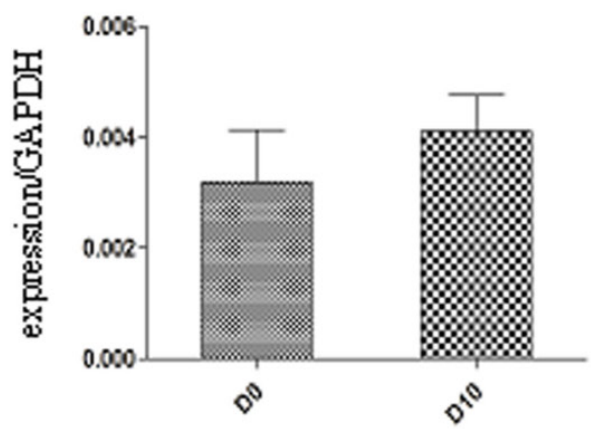

UC007kev.1

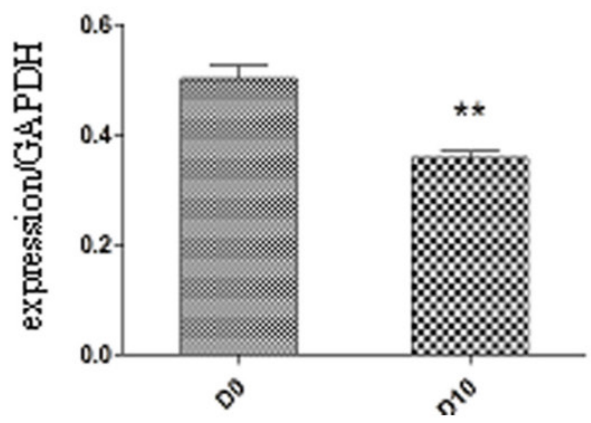

examine alterations in lncRNA expression in the early stage of differentiation.

\section{ENSMUS T0000012450}

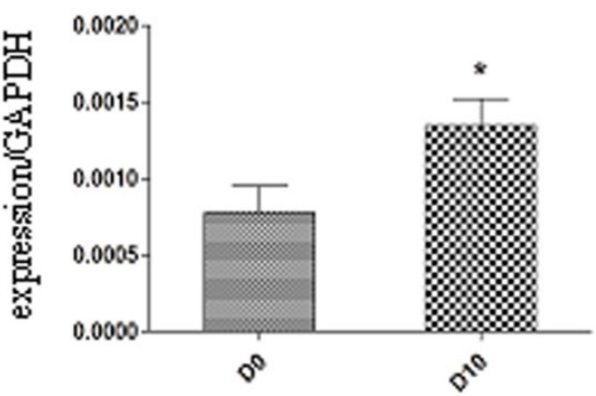

vc009byc.1

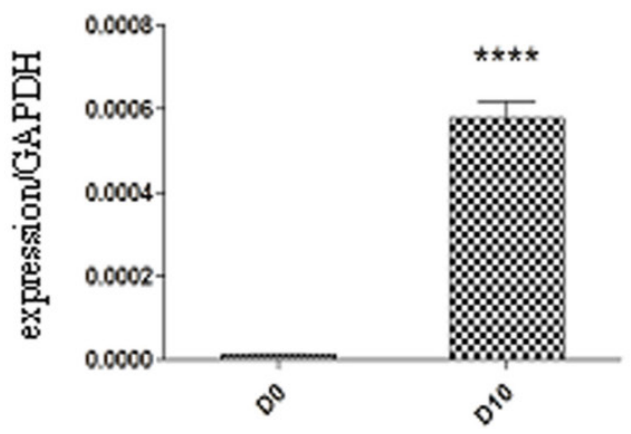

AKO28257

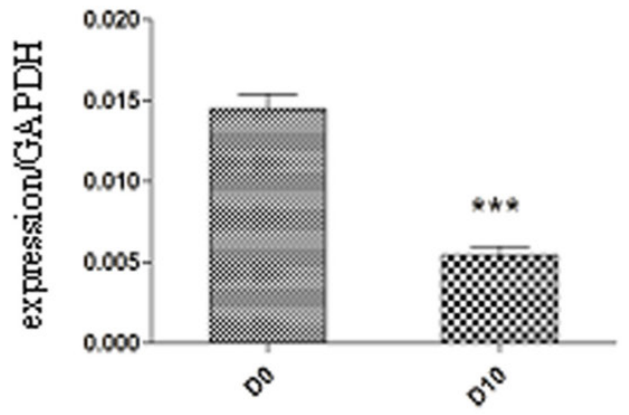

$\mathrm{BC} 030682$

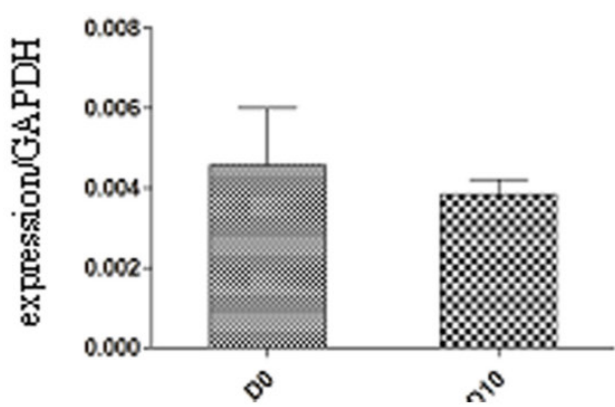

Figure 4: Validation of IncRNA microarray data using real-time RT-PCR. The real-time RT-PCR reactions were repeated three times for every IncRNA. $* \mathrm{p}<0.05,{ }^{*} \mathrm{p}<0.01, * * * \mathrm{p}<0.001$. 


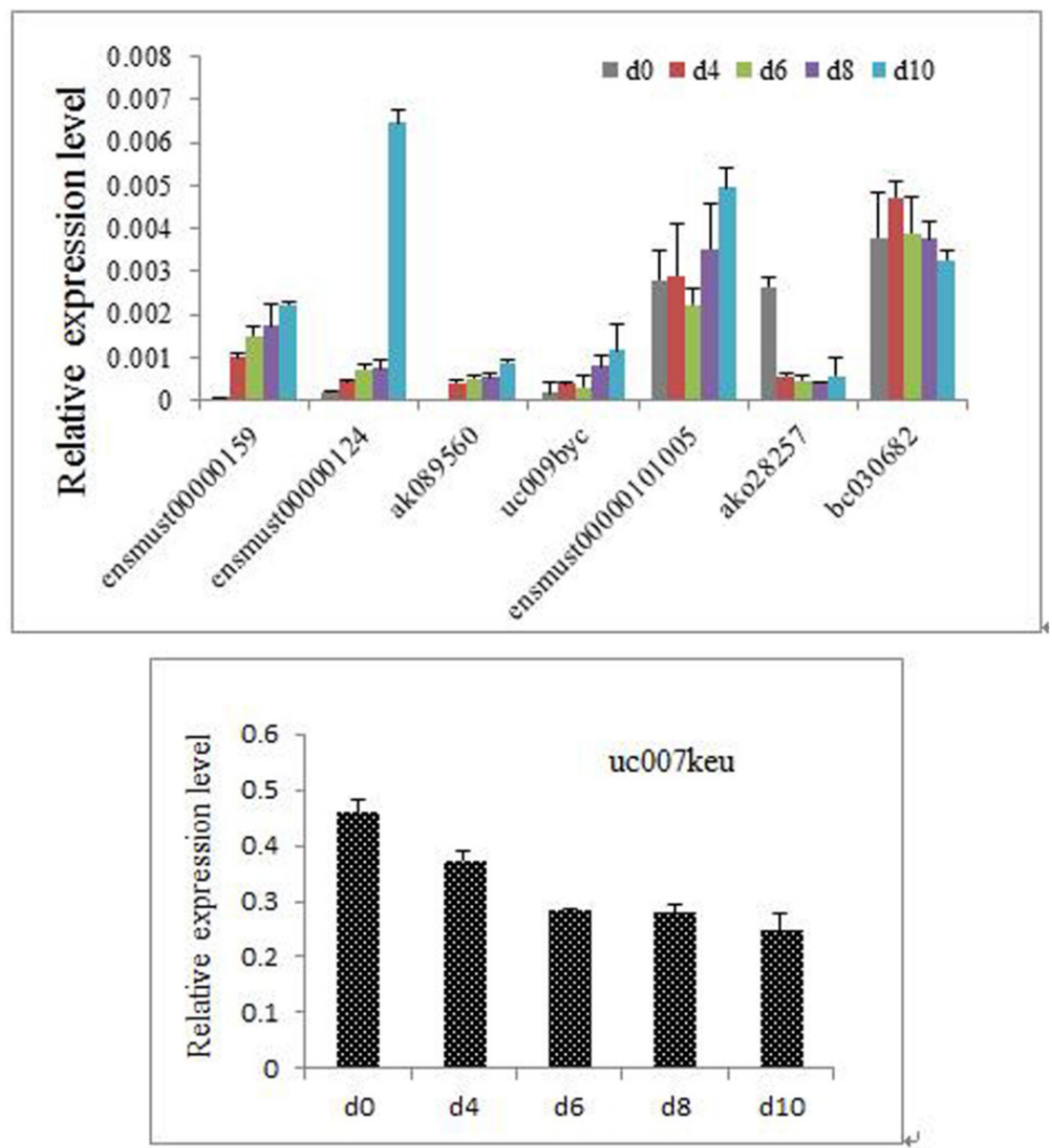

Figure 5. The 8 differentiated expressed IncRNAs at different time points of the differentiation. (Because the relative expression of uc007keu was much higher than the other IncRNAs, we performed two histograms for clarity and aesthetic feeling.)

\section{Materials and methods \\ P I 9 cell culture and induction of differentiation}

P19 cells were bought from the American Type Culture Collection (ATCC, Manassas, VA, USA). The cells were cultured in complete medium (a-MEM + $10 \%$ fetal bovine serum, FBS $+100 \mathrm{U} / \mathrm{ml}$ penicillin + $100 \mathrm{ug} / \mathrm{ml}$ streptomycin, $\mathrm{pH}$ 7.2-7.4) (a-MEM, FBS, penicillin and streptomycin, Gibco-BRL, Grand Island, NY, USA) in a $5 \% \mathrm{CO}_{2}$ atmosphere at $37^{\circ} \mathrm{C}$. During differentiation, P19 cells were maintained in suspension as aggregates for 4 days in complete medium containing $1 \%$ dimethylsulfoxide (DMSO, Sigma, St. Louis, MO, USA) in bacteriological dishes. On day 4, the cell aggregates were transferred to cell culture flasks and then adherently cultivated from the $5^{\text {th }}$ to the $10^{\text {th }}$ day without DMSO. The culture medium was replaced every 2 days. We harvested cells on differentiation day 0 and day 10 . The morphological changes in P19 cells were observed under an inverted microscope (Nikon Eclipse TE300, Tokyo, Ja- pan) equipped with phase-contrast objectives and a digital camera (Nikon E4500).

\section{Quantitative real time-PCR (qPCR) and western blotting}

Total RNA was extracted from the harvested cells using a mirVana extraction kit (Ambion, Austin, TX, USA), following the manufacturer's protocol. RNA was measured using a NanoDrop spectrophotometer (NanoDrop, Wilmington, DE, USA) to assess its quantity and quality, and stored at $-80^{\circ} \mathrm{C}$. In general, we simultaneously performed RNA extraction and cDNA transcription for all subjects. The total RNA was reverse-transcribed to cDNA with a High-Capacity cDNA reverse transcription kit (Applied Biosystems, Austin, USA.). According to the manufacturer's protocol, we used $1 \mu \mathrm{g}$ of mRNA to activate $20 \mu \mathrm{l}$ of the reverse transcription reaction. The reaction comprised $25^{\circ} \mathrm{C}$ for $10 \mathrm{~min}, 37^{\circ} \mathrm{C}$ for $120 \mathrm{~min}$, $85^{\circ} \mathrm{C}$ for $5 \mathrm{~min}$ and a hold at $4^{\circ} \mathrm{C}$. Subsequently, real-time PCR was performed in triplicate for each sample and included no-template negative controls. For the final volume of $20 \mu \mathrm{l}$ reaction, $1 \mu \mathrm{l}$ of synthe- 
sized cDNA was mixed with $8 \mu 1$ of diethylpyrocarbonate (DEPC)-treated water, $10 \mu \mathrm{l}$ of TaqMan Gene Expression Master Mix and $1 \mu \mathrm{l}$ of cardiac troponin $\mathrm{T}$ (cTnT) / $\beta$-actin TaqMan Gene Expression Assay (Applied Biosystems, cTnT ID: Mm01290256_m, $\beta$-actin ID: Mm00607939_s1). The reaction conditions comprised $50^{\circ} \mathrm{C}$ for $2 \mathrm{~min}, 95^{\circ} \mathrm{C}$ for $10 \mathrm{~min}$; followed by 40 cycles of $95^{\circ} \mathrm{C}$ for $15 \mathrm{~s}$ and $60^{\circ} \mathrm{C}$ for $1 \mathrm{~min}$ on the ABI 7500 Real-Time PCR system (Applied Biosystems). $\beta$-actin was used as a reference to obtain the relative expression of cTnT, which was determined with the comparative cycle threshold (CT) (2- $\triangle \mathrm{CT})$ method, in which $\triangle \mathrm{CT}=\mathrm{C}_{\mathrm{T} \text { cTnT }}-\mathrm{C}_{\mathrm{T} \beta \text {-actin }}$.

A monoclonal rabbit anti-cTnT antibody and a monoclonal rabbit anti- $\beta$-actin antibody were purchased from Santa Cruz Biotechnology (Santa Cruz, CA, USA). Cells were broken using the lysis buffer provided in the total protein extraction kits (KeyGen, Inc., China). The lysate supernatant was obtained after centrifugation at $14000 \times \mathrm{g}$ for $30 \mathrm{~min}$ at $4^{\circ} \mathrm{C}$. We then measured the protein concentration with a BCA protein detection kit (KeyGen, Inc., China). Western blotting was conducted as previously described [16].

\section{Construction of the IncRNA microarray}

We pooled three replicate samples of cells on day 0 and day 10 of DMSO exposure, respectively, to perform lncRNA microarray analysis. Total RNA was isolated from the two samples as above and was quantified using a NanoDrop spectrophotometer (NanoDrop). RNA integrity was assessed by standard denaturing agarose gel electrophoresis. Each sample was then amplified and transcribed into fluorescent cRNA along the entire length of the transcripts without $3^{\prime}$ bias, using a random priming method. The labeled cRNAs were hybridized onto the Mouse LncRNA Array v2.0 (8 x 60K, Arraystar). The hybridized arrays were washed, fixed and scanned with using the Agilent DNA Microarray Scanner (part number G2505C). Data were extracted using Agilent Feature Extraction software (version 11.0.1.1). Quantile normalization and subsequent data processing were performed using the GeneSpring GX v11.5.1 software package (Agilent Technologies). Differentially expressed LncRNAs between the two samples were identified by Fold Change filtering. The threshold set for upregulated lncRNAs was more than five-fold and for downregulated IncRNAs it was more than three-fold. The lncRNAs discussed in this article were carefully collected from the most authoritative databases, such as RefSeq, UCSC Knowngenes, Ensembl and many related literature.

\section{Validation of differentially expressed IncRNAs}

Total RNA extraction and cDNA transcription were conducted as above. For real-time PCR, we added $1 \mu \mathrm{l}$ of cDNA to $12.5 \mu \mathrm{l}$ of SYBR-Green Gene Expression Master Mix (Applied Biosystems, Inc), $10.5 \mu \mathrm{f}$ DEPC-treated water and $0.5 \mu \mathrm{l}$ of reverse and forward primers. cDNA was amplified for 50 cycles on the ABI 7500 Real-Time PCR system (Applied Biosystems). The primers sequences used are listed in Table 3. GAPDH was used as a reference to obtain the relative expression of target lncRNAs which was determined with the comparative cycle threshold (CT) $\left(2^{-\triangle \mathrm{CT}}\right)$ method, in which $\triangle \mathrm{CT}=\mathrm{C}_{\mathrm{T}}$ target IncRNA $-\mathrm{C}_{\mathrm{T}}$ GAPDH.

Table 3. Primers for real-time RT-PCR.

\begin{tabular}{lll}
\hline Gene name & Primers & $\begin{array}{l}\text { Tm } \\
\left({ }^{\circ} \mathrm{C}\right)\end{array}$ \\
\hline ENSMUST00000159006 & P5:GGAGCTGACTTGGAGCACTG & 60 \\
& P3:AACAGACCTCTTGCCAGTTCA & \\
uc009byc.1 & P5:AACTTGCGTCTGGAGTTGGG & 60 \\
& P3:CCCAGAATAGCAGCACCTCA & \\
AK089560 & P5:ATGCTTTCCCAGGGTGTGT & 60 \\
& P3:GGCTAGGATTTCCGACGAG & \\
ENSMUST00000101005 & P5:TGTTGATACAGCCTCAGTCCAT & 60 \\
& P3:GTTGGAAGTGGCGAGTTTGG & \\
ENSMUST00000124503 & P5:GACACGAAGAAGAACCACATCA & 60 \\
& P3:GCCTGCGAGGATTCTATTTATT & \\
uc007keu.1 & P5:AAAATGTGATTGGAGCCAGAAG & 60 \\
& P3:GTCCTCTCCTCCCTTGTTTCT & \\
AK028257 & P5:CTCTCCTCTCCGCTTCTCTCT & 60 \\
BC030682 & P3:CATCCCAGCACAAATCAATGT & \\
& P5:GACCTGGCTCTTCCTCAT & 60 \\
GAPDH & P3:TTCCATCTGTCCGTTCTG & \\
& P5:ATTCAACGGCACAGTCAA & 60 \\
& P3:CTCGCTCCTGGAAGATGG & \\
\hline
\end{tabular}

\section{Statistical analysis}

All statistical analyses were performed using the Student's t-test with SPSS software version 13.0 (SPSS, Inc, Chicago, IL, USA). P-values less than 0.05 were considered statistically significant, and all the statistical tests were two-sided.

\section{Conclusion}

In conclusion, we identified a set of lncRNAs that were aberrantly expressed in cardiomyocytes compared to undifferentiated P19 cells, which will provide the foundation for the further study of the biological function of lncRNAs and the mechanism of heart development.

\section{Abbreviations}

lncRNAs: long non-coding RNAs; cTnT: cardiac troponin T; RT-PCR: reverse transcriptase polymerase chain reaction; mRNA: messenger RNAs; miRNA: microRNA; DMSO: dimethylsulfoxide; CHD: con- 
genital heart defects; DEPC: diethylpyrocarbonate.

\section{Acknowledgments}

This work was supported by grants from the National Natural Science Foundation of China (Grant No. 81070500), the Key Medical Personnel Foundation of Jiangsu Province (Grant No. RC2011021), the Nanjing Medical Science and Technique Development Foundation (QRX11107), and the Science and Technology Development Foundation of Nanjing Medical University (Grant No. 2012NJMU195).

\section{Competing Interests}

The authors have declared that no competing interest exists.

\section{References}

1 Zhao Y, Ransom JF, Li A, Vedantham V, von Drehle M, Muth AN, Tsuchihashi T, McManus MT, Schwartz RJ, Srivastava D. Dysregulation of cardiogenesis, cardiac conduction, and cell cycle in mice lacking mirna-1-2. Cell 2007:129:303-317.

2 Meberg A, Lindberg H, Thaulow E. Congenital heart defects: the patients who die. Acta Paediatr 2005:94:1060-1065.

3 Bartel DP. Micrornas: genomics, biogenesis, mechanism, and function. Cell 2004;116:281-297.

4 Ambros V. The functions of animal micrornas. Nature 2004;431:350-355.

5 Saxena A, Carninci P. Long non-coding rna modifies chromatin: epigenetic silencing by long non-coding rnas. Bioessays 2011;33:830-839.

6 Kaikkonen MU, Lam MT, Glass CK. Non-coding rnas as regulators of gene expression and epigenetics. Cardiovasc Res 2011;90:430-440.

7 Tsai MC, Manor O, Wan Y, Mosammaparast N, Wang JK, Lan F, Shi Y, Segal E, Chang HY. Long noncoding rna as modular scaffold of histone modification complexes. Science 2010;329:689-693.

8 Ji P, Diederichs S, Wang W, Boing S, Metzger R, Schneider PM, Tidow N, Brandt B, Buerger H, Bulk E, Thomas M, Berdel WE, Serve H, Muller-Tidow C. Malat-1, a novel noncoding rna, and thymosin beta4 predict metastasis and survival in early-stage non-small cell lung cancer. Oncogene 2003;22:8031-8041.

9 Panzitt K, Tschernatsch MM, Guelly C, Moustafa T, Stradner M, Strohmaier HM, Buck CR, Denk H, Schroeder R, Trauner M, Zatloukal K. Characterization of hulc, a novel gene with striking up-regulation in hepatocellular carcinoma, as noncoding rna. Gastroenterology 2007;132:330-342.

10 Gupta RA, Shah N, Wang KC, Kim J, Horlings HM, Wong DJ, Tsai MC, Hung T, Argani P, Rinn JL, Wang Y, Brzoska P, Kong B, Li R, West RB, van de Vijver MJ, Sukumar S, Chang HY. Long non-coding rna hotair reprograms chromatin state to promote cancer metastasis. Nature 2010;464:1071-1076.

11 Skerjanc IS. Cardiac and skeletal muscle development in p19 embryonal carcinoma cells. Trends Cardiovasc Med 1999;9:139-143.

12 van der Heyden MA, Defize LH. Twenty one years of p19 cells: what an embryonal carcinoma cell line taught us about cardiomyocyte differentiation. Cardiovasc Res 2003;58:292-302.

13 Hu DL, Chen FK, Liu YQ, Sheng YH, Yang R, Kong XQ, Cao KJ, Gu HT, Qian LM. Gata-4 promotes the differentiation of p19 cells into cardiac myocytes. Int J Mol Med 2010;26:365-372

14 Han SP, Pan Y, Peng YZ, Gu XQ, Chen RH, Guo XR. Folbp1 promotes embryonic myocardial cell proliferation and apoptosis through the wnt signal transduction pathway. Int J Mol Med 2009;23:321-330.

15 van der Heyden MA, van Kempen MJ, Tsuji Y, Rook MB, Jongsma HJ, Opthof T: P19 embryonal carcinoma cells: a suitable model system for cardiac electrophysiological differentiation at the molecular and functional level. Cardiovasc Res 2003;58:410-422.

16 Kaczocha M, Glaser ST, Deutsch DG. Identification of intracellular carriers for the endocannabinoid anandamide. Proc Natl Acad Sci U S A 2009:106:6375-6380.

17 van der Heyden MA, Defize LH. Twenty one years of p19 cells: what an embryonal carcinoma cell line taught us about cardiomyocyte differentiation. Cardiovasc Res 2003;58:292-302.

18 Trojnarska O, Grajek S, Katarzynski S, Kramer L. Predictors of mortality in adult patients with congenital heart disease. Cardiol J 2009;16:341-347.

19 Olson EN. Gene regulatory networks in the evolution and development of the heart. Science 2006;313:1922-1927.

20 Bruneau BG. The developmental genetics of congenital heart disease. Nature 2008;451:943-948.

21 Skerjanc IS: Cardiac and skeletal muscle development in p19 embryonal carcinoma cells. Trends Cardiovasc Med 1999:9:139-143.
22 Kung JT, Colognori D, Lee JT. Long noncoding rnas: past, present, and future. Genetics 2013;193:651-669.

23 Collins K. Physiological assembly and activity of human telomerase complexes. Mech Ageing Dev 2008;129:91-98.

24 Plath K, Mlynarczyk-Evans S, Nusinow DA, Panning B. Xist rna and the mechanism of $x$ chromosome inactivation. Annu Rev Genet 2002;36:233-278.

25 Orom UA, Derrien T, Beringer M, Gumireddy K, Gardini A, Bussotti G, Lai F, Zytnicki M, Notredame C, Huang Q, Guigo R, Shiekhattar R. Long noncoding rnas with enhancer-like function in human cells. Cell 2010;143:46-58.

26 Huarte M, Guttman M, Feldser D, Garber M, Koziol MJ, Kenzelmann-Broz D, Khalil AM, Zuk O, Amit I, Rabani M, Attardi LD, Regev A, Lander ES, Jacks T, Rinn JL. A large intergenic noncoding rna induced by p53 mediates global gene repression in the p53 response. Cell 2010;142:409-419.

27 Ebisuya M, Yamamoto T, Nakajima M, Nishida E. Ripples from neighbouring transcription. Nat Cell Biol 2008;10:1106-1113.

28 Ponjavic J, Oliver PL, Lunter G, Ponting CP. Genomic and transcriptional co-localization of protein-coding and long non-coding rna pairs in the developing brain. PLoS Genet 2009;5:e1000617.

29 Grote P, Wittler L, Hendrix D, Koch F, Wahrisch S, Beisaw A, Macura K, Blass G, Kellis M, Werber M, Herrmann BG. The tissue-specific lncrna fendrr is an essential regulator of heart and body wall development in the mouse. Dev Cell 2013;24:206-214

30 Klattenhoff CA, Scheuermann JC, Surface LE, Bradley RK, Fields PA, Steinhauser ML, Ding H, Butty VL, Torrey L, Haas S, Abo R, Tabebordbar M, Lee RT, Burge CB, Boyer LA. Braveheart, a long noncoding rna required for cardiovascular lineage commitment. Cell 2013;152:570-583.

31 Morales D, Hechavarria R, Wojna V, Acevedo SF. Ywhae/14-3-3epsilon: a potential novel genetic risk factor and csf biomarker for hiv neurocognitive impairment. J Neurovirol 2013.

32 Toyo-oka K, Shionoya A, Gambello MJ, Cardoso C, Leventer R, Ward HL, Ayala R, Tsai LH, Dobyns W, Ledbetter D, Hirotsune S, Wynshaw-Boris A. 14-3-3epsilon is important for neuronal migration by binding to nudel: a molecular explanation for miller-dieker syndrome. Nat Genet 2003;34:274-285.

33 Liu J, Li ZQ, Li JY, Li T, Wang T, Li Y, Xu YF, Feng GY, Shi YY, He L: Polymorphisms and haplotypes in the ywhae gene increase susceptibility to bipolar disorder in chinese han population. J Clin Psychiatry 2012;73:e1276-e1282.

34 Croce S, Hostein I, Ribeiro A, Garbay D, Velasco V, Stoeckle E, Guyon F, Floquet A, Neuville A, Coindre JM, Macgrogan G, Chibon F.: Ywhae rearrangement identified by fish and rt-pcr in endometrial stromal sarcomas: genetic and pathological correlations. Mod Pathol 2013

35 Mercer TR, Dinger ME, Sunkin SM, Mehler MF, Mattick JS. Specific expression of long noncoding rnas in the mouse brain. Proc Natl Acad Sci U S A 2008;105:716-721. 